\title{
Caspase Cascades in Human Immunodeficiency Virus-Associated Neurodegeneration
}

\author{
Gwenn A. Garden, ${ }^{1,2,3}$ Samantha L. Budd, ${ }^{2,3}$ Elena Tsai, ${ }^{3}$ Lisa Hanson, ${ }^{1}$ Marcus Kaul, ${ }^{2,3}$ Danielle M. D'Emilia, ${ }^{3}$ \\ Robert M. Friedlander, ${ }^{3}$ Junying Yuan, ${ }^{4}$ Eliezer Masliah, ${ }^{5}$ and Stuart A. Lipton ${ }^{2,3,5}$ \\ ${ }^{1}$ Department of Neurology, University of Washington, Seattle, Washington 98195, ${ }^{2}$ Center for Neuroscience and Aging, \\ The Burnham Institute, La Jolla, California 92037, ${ }^{3}$ Neuroapoptosis Laboratory and CNS Research Institute, Department \\ of Neurosurgery, Brigham and Women's Hospital, Harvard Medical School, Boston, Massachusetts 02115, ${ }^{4}$ Department \\ of Cell Biology, Harvard Medical School, Boston, Massachusetts 02115, and ${ }^{5}$ Department of Neurosciences, University \\ of California, San Diego, La Jolla, California 92037
}

Many patients infected with human immunodeficiency virus-1 (HIV-1) develop a syndrome of neurologic deterioration known as HIV-associated dementia (HAD). Neurons are not productively infected by HIV-1; thus, the mechanism of HIV-induced neuronal injury remains incompletely understood. Several investigators have observed evidence of neuronal injury, including dendritic degeneration, and apoptosis in CNS tissue from patients with HAD. Caspase enzymes, proteases associated with the process of apoptosis, are synthesized as inactive proenzymes and are activated in a proteolytic cascade after exposure to apoptotic signals. Here we demonstrate that HAD is associated with active caspase-3-like immunoreactivity that is localized to the soma and dendrites of neurons in affected regions of the human brain. Additionally, the cascade of caspase activation was studied using an in vitro model of
HIV-induced neuronal apoptosis. Increased caspase-3 proteolytic activity and mitochondrial release of cytochrome $c$ were observed in cerebrocortical cultures exposed to the HIV coat protein gp120. Specific inhibitors of both the Fas/tumor necrosis factor- $\alpha$ /death receptor pathway and the mitochondrial caspase pathway prevented gp120-induced neuronal apoptosis. Caspase inhibition also prevented the dendrite degeneration observed in vivo in transgenic mice with CNS expression of HIV/gp120. These findings suggest that pharmacologic interventions aimed at the caspase enzyme pathways may be beneficial for the prevention or treatment of HAD.

Key words: apoptosis; caspase; dendrite degeneration; deconvolution microscopy; HIV-associated dementia; tumor necrosis factor
Approximately $20-40 \%$ of patients infected with human immunodeficiency virus-1 (HIV-1) develop HIV-associated dementia (HAD) (McArthur et al., 1993), a neurodegenerative syndrome characterized by cognitive decline, personality change, and motor deficits (Lipton and Gendelman, 1995). The neuropathology that can be associated with HAD includes HIV encephalitis (HIVE) with prominent microglial activation, neuronal loss, dendritic simplification, and decreased synaptic density (Masliah et al., 1996). Nuclear changes characteristic of apoptosis have been observed in both neurons and non-neuronal cells (Adle-Biassette et al., 1995; Gelbard et al., 1995; Petito and Roberts, 1995; Shi et al., 1996). Neurons are not productively infected by HIV-1. Hence, how HIV infection causes neuronal injury and apoptosis is not completely understood (Kaul et al., 2001).

One proposed mechanism for HIV-related neuronal damage involves release of viral proteins (Brenneman et al., 1988; Dreyer

\footnotetext{
Received Sept. 14, 2001; revised Feb. 1, 2002; accepted Feb. 15, 2002.

This work was supported by The Wellcome Trust (S.L.B.), AmFAR (M.K.), and National Institutes of Health grants to G.A.G. and S.A.L. We thank Timothy Lishnak and Satjiv Kohli for technical assistance and Dr. M. Johnson, R. Morrison, T. Moller, and Y. Kinoshita for comments on this manuscript. We also thank Dr. L. Mucke for the generous gift of gp120 transgenic mice. Human tissue was obtained from the University of California, San Diego HIV Neurobehavioral Research Center.

Correspondence should be addressed to Dr. Gwenn Garden, Department of Neurology, Box 356465, University of Washington, Seattle, WA 98195, E-mail: gagarden@u.washington.edu; or Dr. Stuart A. Lipton, Center for Neuroscience and Aging, The Burnham Institute, La Jolla, California 92037, E-mail: slipton@burnham.org.

Copyright (C) 2002 Society for Neuroscience $\quad 0270-6474 / 02 / 224015-10 \$ 15.00 / 0$
}

et al., 1990; Adamson et al., 1996; New et al., 1997; Kruman et al., 1998; Yeung et al., 1998; Huang et al., 2000; Patel et al., 2000; Trillo-Pazos et al., 2000) from HIV-infected immune cells (macrophages and microglia). Among the viral proteins studied, the coat protein gp120 manifests neurotoxic effects in both primary human CNS cultures (Yeung et al., 1995) and transgenic mice (Toggas et al., 1994). HIV-1/gp120 binds to CD4 and to specific chemokine receptors on immune cells. Many neurons and astrocytes also bear chemokine receptors (Hesselgesser et al., 1998; Lavi et al., 1998; Meucci et al., 1998; Zheng et al., 1999). On isolated neurons, HIV/gp120 may promote apoptosis directly (Hesselgesser et al., 1998; Meucci et al., 1998; Zheng et al., 1999). However, we showed previously that, in mixed neuronal-glial cultures, the predominant neurotoxicity of HIV/gp120 depends on the activation of microglial chemokine receptors rather than a direct effect on neurons (Kaul and Lipton, 1999). Pathophysiologically relevant (picomolar) concentrations of HIV/gp120 activate macrophage-microglial cells (Giulian et al., 1993; Kaul and Lipton, 1999) that subsequently release toxic products capable of inducing apoptosis in neurons (Lipton and Gendelman, 1995).

In other systems, apoptosis is mediated by activation of caspases, a family of proteases involved in signal transduction of apoptotic stimuli and ordered cellular disassembly (Stennicke and Salvesen, 2000). Caspases are synthesized as inactive proenzymes and are activated by proteolytic cleavage. Multiple caspases may activate one another in a sequential cascade manner. Caspase- 3 is a frequent downstream effector of the cascade (Stennicke and 


\begin{tabular}{|c|c|c|c|c|c|}
\hline Case & Cause of death & Time to autopsy & HIV status & Neuropsych testing & Neuropathology \\
\hline 1 & Hepatic failure & $4 \mathrm{hr}$ & $\mathrm{HIV}+$ & Impaired & HIVE \\
\hline 2 & Pneumonia & $24 \mathrm{hr}$ & $\mathrm{HIV}+$ & Impaired & HIVE \\
\hline 3 & Pneumonia & $24 \mathrm{hr}$ & $\mathrm{HIV}+$ & Impaired & HIVE \\
\hline 4 & Hepatic failure & $3 \mathrm{hr}$ & $\mathrm{HIV}+$ & Impaired & HIVE \\
\hline 5 & Pneumonia & $16 \mathrm{hr}$ & $\mathrm{HIV}+$ & Impaired & HIVE \\
\hline 6 & Pneumonia & $10 \mathrm{hr}$ & $\mathrm{HIV}+$ & Normal & None \\
\hline 7 & Sepsis & $14 \mathrm{hr}$ & $\mathrm{HIV}+$ & Normal & None \\
\hline 8 & Fungal sepsis & $24 \mathrm{hr}$ & $\mathrm{HIV}+$ & Normal & Fungal vasculitis \\
\hline 9 & Hepatic failure & $24 \mathrm{hr}$ & HIV- & Not available & Type II Alzheimer's gliosis \\
\hline 10 & Hepatic failure & $7 \mathrm{hr}$ & HIV- & Not available & None \\
\hline
\end{tabular}

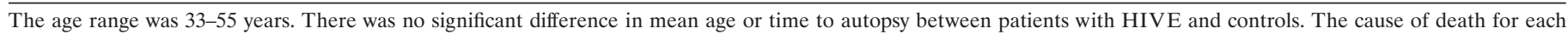
HAD-HIVE case was also represented in the control group. HIV +, HIV positive; HIV-, HIV negative.

Salvesen, 2000) and is activated in several neurodegenerative disorders (Namura et al., 1998; Hartmann et al., 2000; Su et al., 2000). Active caspase-3 was detected by Western blot in human fetal CNS cultures exposed to HIV/gp120 (Zheng et al., 1999), but the specific cell population undergoing caspase activation was not identified. Additionally, postmortem studies on the brains of pediatric patients with HAD manifested an increase in neurons immunoreactive for procaspase-3 (James et al., 1999). In that study, however, the presence of active caspase-3 was not examined.

We demonstrate here that neuronal active caspase-3-like immunoreactivity is significantly elevated in cerebrocortical neurons from patients with HAD, as well as in cultured rodent neurons exposed to HIV/gp120. Neurons exposed to HIV/gp120 undergo activation of two upstream caspases, caspase- 8 and caspase-9, and inhibition of either pathway prevents neuronal apoptosis. Transgenic mice expressing the HIV/gp120 coat protein develop several neuropathologic features associated with HAD, including dendritic degeneration (Toggas et al., 1994). To determine whether caspase enzymes mediate this dendritic injury, we crossed HIV/gp120 transgenic mice with transgenic mice expressing a dominant interfering caspase enzyme (Friedlander et al., 1997). Caspase inhibition in vivo prevents dendritic injury in gp120 transgenic mice. Together, these findings suggest that caspases play an important role in the pathogenesis of HAD.

\section{MATERIALS AND METHODS}

Human tissue. Cerebrocortical tissue from human subjects in a prospective study on HIV-related neurologic disease was collected at the time of autopsy and fixed in formalin. Five patients had HIVE and dementia, documented by neuropathologic examination and premorbid neuropsychological testing, two patients were HIV-1 infected but had no evidence of dementia on premorbid neuropsychological testing, and two additional control patients were HIV-1 seronegative. For additional patient details, please refer to Table 1 .

Animals. Two separate lines of transgenic mice expressing HIV/gp120 under the control of the glial fibrillary acidic protein (GFAP) promoter (obtained from Lennart Mucke, Gladstone Institute, University of California, San Francisco, San Francisco, CA) were crossed with mice expressing a mutated $(\mathrm{C} 285 \mathrm{G})$ and proteolytically inactive form of caspase-1 under the control of the neuron-specific enolase (NSE) promoter. Transgenic expression of this mutant caspase- 1 inhibits interleukin-1 $\beta$ (IL-1 $\beta$ )- and trophic factor withdrawal-induced neuronal death (Friedlander et al., 1997). However, the product of this mutant caspase- 1 transgene may well affect the activity of other caspases and therefore may represent an interfering form (Ona et al., 1999). Mice were housed in an approved animal facility with access to food and water ad libitum. All of the progeny of each cross underwent tail biopsy at 3 weeks of age. The DNA extracted from tail biopsies was assayed for the presence of the gp120 transgene or the caspase interfering transgene (Casp-1/C285G) by PCR. The PCR product was assessed by the presence of an appropriate molecular weight band on ethidium bromide-stained agarose gels. The HIV/gp120 transgenic mice were maintained on a hybrid strain background $(\mathrm{C} 57 \mathrm{BL} / 6 \times \mathrm{SJL})$, and the $\mathrm{C} 285 \mathrm{G}$ mice were bred into a C57BL/6 strain background for more than five generations before this cross. The F2 generation of these initial crosses were used to establish breeding pairs between Casp-1/C285G and gp120 transgenic heterozygotes. To avoid any possible impact of strain on the results of these experiments, all of the animals used in this analysis were F3 progeny of established F2 breeding pairs. Genotype was confirmed by repeat tail biopsy at the time the animal was killed.

Primary cerebrocortical cultures. Embryonic rat cerebrocortical cultures were prepared as described previously (Kaul and Lipton, 1999; Budd et al., 2000). Cultures containing neurons, astrocytes, and microglia were incubated in $200 \mathrm{pm}$ recombinant glycosylated $\mathrm{HIV}_{\mathrm{SF} 2} \mathrm{gp} 120$ (catalog \#386; National Institutes of Health AIDS Research and Reference Reagent Program, Bethesda, MD). After a $24 \mathrm{hr}$ exposure to gp120, cultures were fixed, permeabilized, and stained with Hoechst dye 33342 (Sigma, St. Louis, MO). Apoptotic profiles were identified by the presence of a condensed nuclear morphology, and the ratio of apoptotic nuclei to total nuclei was assessed. The nuclear changes associated with apoptosis observed by the Hoechst staining pattern were confirmed with the Fluorescent Apoptosis Detection System (Promega, Madison, WI). To determine which cell types undergo apoptosis in response to gp120, cultures were immunostained with cell type-specific antibodies recognizing GFAP for astrocytes (Sigma), OX-42 for microglia (Serotec, Indianapolis, IN), and microtubule-associated protein-2 (MAP-2) for neurons (Sigma). There was no increase in apoptosis among astrocytes or microglia, because gp120 causes only neuronal cell death in this culture system (Kaul and Lipton, 1999).

Caspase activity assays. After gp120 exposure, cultures were lysed in caspase assay lysis buffer (1\% sucrose, $0.1 \%$ 3-[(3-cholamidopropyl) dimethylammonio]-1-propanesulfonate, $100 \mathrm{~mm}$ HEPES, and $2 \mathrm{~mm}$ dithiothreitol, $\mathrm{pH}$ 7.4). Lysates were assayed for caspase activity as described previously (Budd et al., 2000). Results are expressed as percentage of increase in arbitrary fluorescence units per milligram of total protein ( $n \geq 3$ for each time point).

Caspase inhibition. Three hours before the addition of gp120, a pan-caspase inhibitor $[50 \quad \mu \mathrm{M} \quad N$-benzyloxycarbonyl-Val-Ala-Aspfluoromethyl ketone (zVAD-fmk)] or a relatively specific caspase peptide inhibitor was added [for caspase-3, $50 \mu \mathrm{M}$ z-Asp-Glu-Val-Aspfluoromethyl ketone (DEVD-fmk); for caspase-8, $20 \mu \mathrm{M}$ z-Ile$\mathrm{Glu}(\mathrm{OMe})$-Thr-Asp(OMe)-fluoromethyl ketone (IETD-fmk); for caspase-9, $20 \mu \mathrm{M}$ benzyloxycarbonyl-Leu-Glu(OMe)-His-Asp(OMe)fluoromethylketone (LEHD-fmk)]. Alternatively, an inactive fmk compound [50 $\mu \mathrm{M}$ 2-Phe-Ala-fluoromethyl ketone (zFA-fmk)] was added as a control (all peptides from Enzyme Systems Products, Livermore, CA).

Active caspase labeling. Cells containing the active form of caspase-3 were labeled with biotinylated acetyl-Asp-Glu-Val-Asp-1-aldehyde (Biomol, Plymouth Meeting, PA) as described previously (Budd et al., 2000). These results were confirmed by immunostaining with a specific antibody recognizing active caspase-3 (1:1000; R \& D Systems, Minneapolis, MN). Cells containing active caspase- 8 were identified using 
SK440 antiserum recognizing only the active form of caspase 8 (1:1000; gift from K. Kilkey, GlaxoSmithKline, King of Prussia, PA) (Velier et al., 1999). Cells with active caspase-9 were immunostained with a polyclonal rabbit antiserum recognizing only the active form of caspase-9 (1:50; Cell Signaling Technology, Beverly, MA).

$T N F-\alpha$ inhibition. Interaction between TNF- $\alpha$ and its receptor was inhibited with $1 \mu \mathrm{g} / \mathrm{ml}$ neutralizing antibody to TNF- $\alpha$ (R \& D Systems), added before addition of gp120. Control cultures received $1 \mu \mathrm{g} / \mathrm{ml}$ nonspecific IgG. Cultures were fixed $24 \mathrm{hr}$ after exposure to gp120, and apoptotic nuclei were scored.

Cytochrome c assay. Cytochrome $c$ release was assessed as described previously (Budd et al., 2000). Cultures exposed to gp120 for 0, 3, or 12 $\mathrm{hr}$ were lysed, and the cytoplasmic and mitochondrial fractions were separated by ultracentrif ugation. Cytochrome $c$ was immunoprecipitated from the cytoplasmic fraction and identified on Western blot.

Immunostaining. Human CNS tissue was embedded in paraffin, sectioned, and mounted on glass slides. After deparaffinization and rehydration, cerebrocortical sections were immunostained with affinitypurified polyclonal rabbit $\mathrm{IgG}$ directed specifically against the active form of caspase-3 (1:1000; R \& D Systems). The active caspase-3 antibody used in these studies was reported previously to detect apoptotic neurons in fixed human brain and colocalized with markers of DNA degradation (Nitsch et al., 2000). Signal amplification was obtained using the ABC Elite detection kit (Vector Laboratories, Burlingame, CA). Controls using preimmune rabbit IgG and preabsorption of the antibody with an abundance of the immunogenic peptide demonstrated no evidence of background immunoreactivity. Mice were killed at 12 months of age by anesthetic overdose and transcardially perfused with normal saline. The forebrain was immediately dissected from the cranium and immersed in $4 \%$ paraformaldehyde. After fixation for $48 \mathrm{hr}, 30-\mu \mathrm{m}$-thick vibratome sections were cut and stored at $-20^{\circ} \mathrm{C}$ in cryoprotective media (30\% glycerol and 30\% ethyleneglycol in phosphate buffer). Dendrites were identified by immunofluorescent labeling with a monoclonal antibody directed against MAP-2 (Roche Products, Hertforshire, UK) at 1:500 dilution and Alexa 488-conjugated anti-mouse IgG at 1:200 dilution (Molecular Probes, Eugene, OR). Immunolabeled sections were mounted on glass slides and covered with a Corning 1.5 cover glass using ProLong antifade mounting media (Molecular Probes).

Quantitative deconvolution microscopy. The volume of neuropil in cerebrocortical tissue sections occupied by MAP-2-positive immunofluorescent processes was measured using quantitative deconvolution microscopy (SlideBook Software; Intelligent Imaging Innovations, Denver, $\mathrm{CO})$. Using a $63 \times$ oil immersion lens and a constant exposure time, $2 \mu \mathrm{M}$ image stacks (z step size of $0.1 \mu \mathrm{M}$ ) were obtained from 10 randomly selected regions of cerebrocortical neuropil per animal. The image stacks were subjected to constrained iterative deconvolution using a point spread function obtained from a fluorescent bead $0.2 \mu \mathrm{m}$ in diameter. Regions occupied by neuronal cell bodies were removed from the analysis. Fluorescent voxels were identified by threshold segmentation. The volume of neuropil occupied by MAP-2-labeled processes was calculated as the ratio of fluorescent to total voxels from the middle (best focus) planes of each image stack. Image stack acquisition, threshold segmentation, and volume calculations were performed by an observer blinded to genotype.

Data analysis. Human tissue samples were examined and scored for caspase-3 immunoreactivity by an observer blinded to the HIV status and neuropsychological test scores for each case. In cerebrocortical culture experiments, Hoechst-labeled nuclei were counted in 10 randomly selected fields using a $40 \times$ objective with a $1.6 \times$ optivar or a $63 \times$ objective. Approximately 1000 nuclei were counted per condition in each experiment. To determine the percentage of apoptotic cells attributable to a specific treatment, the mean percentage of apoptotic nuclei in control (untreated) cultures was subtracted. Similarly, to determine the percentage of neurons containing the active form of caspase- 3 attributable to a specific treatment, the small percentage of active caspase-3positive neurons in control cultures was subtracted. For each figure, the minimum number of cultures used in each experimental condition was $n=3$. Statistical analysis was performed using an ANOVA and Fisher's PLSD post hoc test on StatView 5.0 software (SAS Institute, Cary, NC).

\section{RESULTS}

\section{Caspase-3 activity in HAD}

To examine neuronal caspase- 3 activation in the brains of patients with HIV-related neurodegeneration, immunohistochemistry

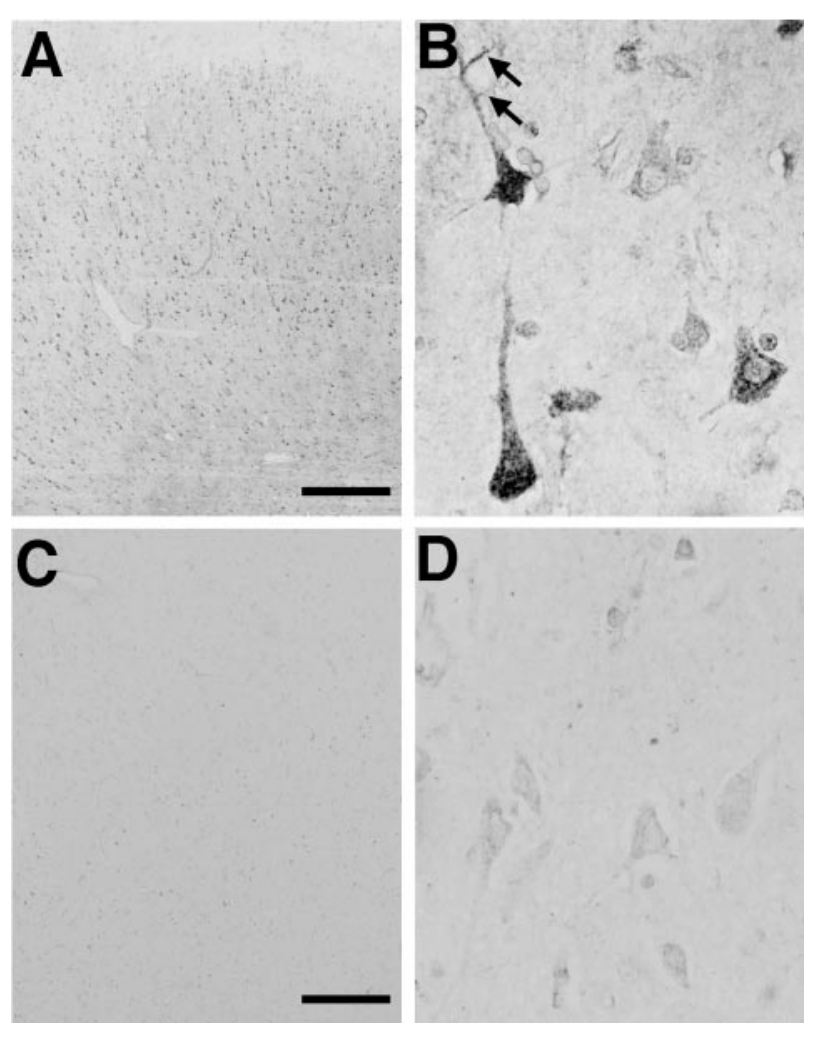

Figure 1. Caspase-3 is activated in cerebrocortical neurons from patients with HAD and HIVE. Low $(A)$ - and high $(B)$-power micrographs of cortical sections from patients with HIVE manifested diffuse active caspase-3 immunoreactivity in cortical neurons. The majority of active caspase-3-positive neurons displayed punctate immunoreactivity in the cell body and proximal dendrites. Some secondary dendrites were also labeled (arrows). Low $(C)$ - and high $(D)$-power micrographs of cortical tissue from an HIV-negative patient demonstrate that cerebrocortical neurons from HIV-negative control subjects (as well as from HIVpositive patients with no premorbid evidence of cognitive impairment; data not shown) have scant or no active caspase-3 immunoreactivity.

was performed on cerebrocortical tissue sections with an affinitypurified rabbit antiserum that recognizes only the active form of caspase-3 (Fig. 1) (see Materials and Methods). Five patients with HIVE and documented premorbid cognitive impairment (HIVE-HAD) were compared with a control group containing two HIV-negative individuals and three HIV-positive cases with no evidence for HIVE or cognitive decline. Details on the HIV status, cognitive impairment, cause of death, and time to autopsy for each patient included in the study are reported in Table 1. Sections from HIVE-HAD patients contained numerous cortical neurons decorated with active caspase-3 immunoreactivity (Fig. $1 A, B)$. The majority of labeled neurons manifest a punctate cytoplasmic and dendritic distribution of immunoreactivity for active caspase-3 (Fig. 1B). Nuclear localization of active caspase-3 and morphologic changes associated with apoptosis were infrequently observed in cortical neurons from this population. The predominantly cytoplasmic pattern of immunoreactivity suggests that active caspase- 3 is present before the morphological features of apoptosis, as has also been demonstrated recently in other neurodegenerative disorders using additional antibodies directed against active caspase-3 (Hartmann et al., 2000; Su et al., 2000). Tissue from nondemented HIV-infected patients and uninfected control subjects showed scant immunologic evidence of active caspase-3 in neurons (Fig. $1 C, D)$. Anti- 


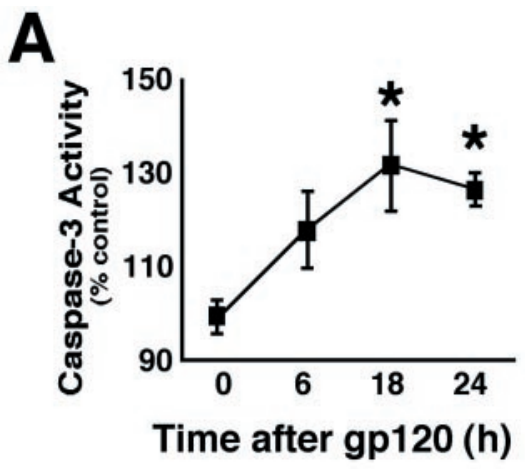

Figure 2. Cultured rat cerebrocortical cells exposed to $\mathrm{HIV/gp120} \mathrm{manifest} \mathrm{caspase-3} \mathrm{activity}$ and undergo caspase-dependent neuronal apoptosis. $A$, Caspase-3-like activity (DEVD cleavage) was significantly increased over control cultures after $18-24 \mathrm{hr}$ exposure to $200 \mathrm{pm}$ gp120 ( ${ }^{*} p<$ $0.01 ; n=3) . B$, Exposure to gp120 produced a statistically significant increase in apoptosis that was prevented by zVAD-fmk or DEVD-fmk but not by zFA-fmk ( $n=9$ from 3 independent experiments). $C, \mathrm{~A}$ number of neurons identified with anti-MAP-2 (red) also contained active caspase-3 (green; arrows). D, The percentage of MAP-2positive neurons labeled with active caspase-3 greatly increased in cultures exposed to gp120 for $24 \mathrm{hr}\left({ }^{*} p<0.001 ; n=6\right.$ from 2 independent experiments)
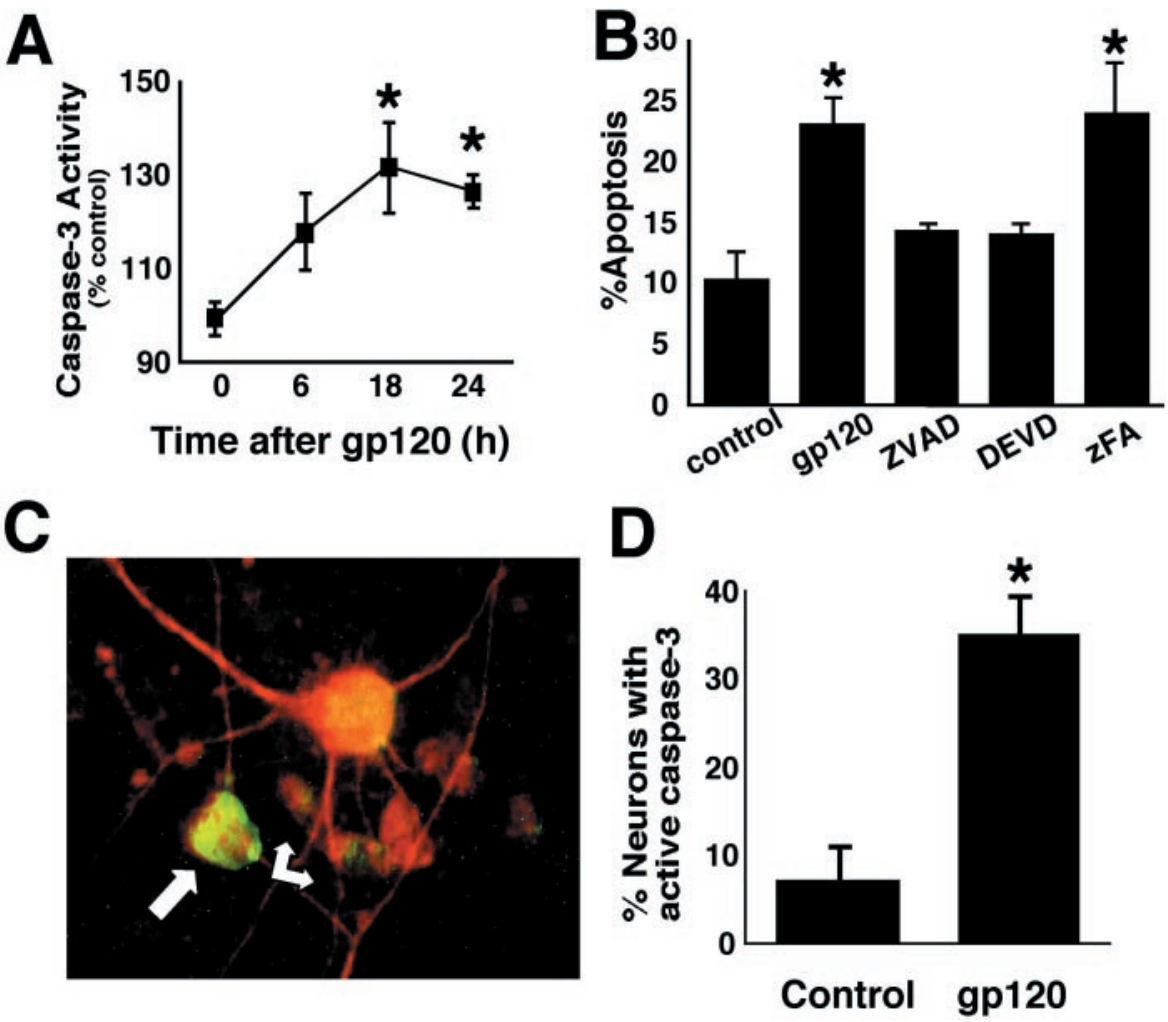

active caspase-3-positive neurons were counted in 10 randomly selected $40 \times$ fields by an observer blinded to clinical status. We found a significant increase in the mean number of active caspase-3 immunolabeled cortical neurons per $40 \times$ field $(6.0 \pm$ 0.5 vs $1.0 \pm 0.5 ; p<0.0001)$ in cases of symptomatic HIVE compared with controls.

\section{HIV/gp120 induces caspase-mediated neuronal apoptosis}

To determine whether gp120 promotes activation of caspase enzymes, we exposed rat cerebrocortical cultures to HIV/gp120 (200 pM). We chose to use recombinant HIV/gp120 from the SF2 strain of the virus because this gp120 preparation is purified from a mammalian cell expression system allowing appropriate posttranslational modifications and preventing contamination with bacterial proteins. It has been the most extensively used gp120 in previous in vitro studies and is the gp120 amino acid sequence used to generate gp120 transgenic mice (Toggas et al., 1994).

Caspase activity in cerebrocortical cultures was assessed by fluorogenic substrate assay at several time points after HIV/gp120 exposure (Fig. $2 \mathrm{~A}$ ). A significant increase in caspase-3-like activity was observed within $18 \mathrm{hr}$ of gp120 exposure. Competitive inhibition of caspase activity with a peptide inhibitor of all caspases (zVAD-fmk) or a relatively specific caspase-3 inhibitor (DEVD-fmk) prevented gp120-induced apoptosis (Fig. 2B). To determine whether active caspase- 3 was present specifically in neurons, cultures were double labeled with anti-active caspase-3 and anti-MAP-2 (Fig. 2C). HIV/gp120 resulted in a significant increase in the percentage of neurons containing active caspase-3 (Fig. 2D). Together, these data demonstrate that gp120 causes caspase-3-mediated neuronal apoptosis in vitro. This finding supports the hypothesis that active caspase- 3 in postmortem brains of patients with symptomatic HIVE maybe secondary to HIVmediated induction of caspases.

\section{HIV/gp120-induced neuronal apoptosis involves death receptor-mediated caspase activation}

The death receptor-mediated caspase cascade is associated with signaling through cell surface receptors coupled to caspase- 8 activity, whereas the mitochondrial-mediated pathway results in activation of caspase- 9 activity. Eventually, either cascade leads to activation of effector caspase-3. The death receptor pathway is triggered by activation of the TNF- $\alpha$ receptor (TNFR) family. Ligand binding to TNFR family members results in clustering into a trimeric receptor complex. Through defined protein interactions, receptor clustering brings multiple copies of caspase- 8 into close proximity, allowing its auto-activation by self-cleavage (Imai et al., 1999; Salvesen and Dixit, 1999). Activated microglia release a variety of proapoptotic inflammatory cytokines (Lipton and Gendelman, 1995), including TNF- $\alpha$. TNF- $\alpha$ has been reported to contribute to apoptosis in human neuronal cell lines and primary neuronal cultures (Talley et al., 1995; Pulliam et al., 1998). Furthermore, brain and CSF from HAD patients manifest increased mRNA and protein for TNF- $\alpha$ and its receptors (Sippy et al., 1995). Thus, we hypothesized that death receptor-mediated caspase activation may participate in gp120-induced neuronal apoptosis.

To determine whether TNF- $\alpha$ and the death receptor pathway are involved in gp120-induced neuronal apoptosis, we used a specific TNF- $\alpha$ neutralizing antibody to prevent signaling through TNFRs and a specific caspase- 8 inhibitor, respectively. TNF- $\alpha$ neutralizing antibody $(1 \mu \mathrm{g} / \mathrm{ml})$ prevented gp 120 -induced neuronal apoptosis in mixed neuronal-glial cerebrocortical cultures (Fig. 3A). We also found that neuronal caspase-3 activation and apoptosis secondary to gp120 exposure were prevented by a $3 \mathrm{hr}$ preincubation with IETD-fmk, a relatively specific inhibitor of caspase-8 (Fig. 3B,C).

TNFRs are expressed in multiple cell types in the brain, 


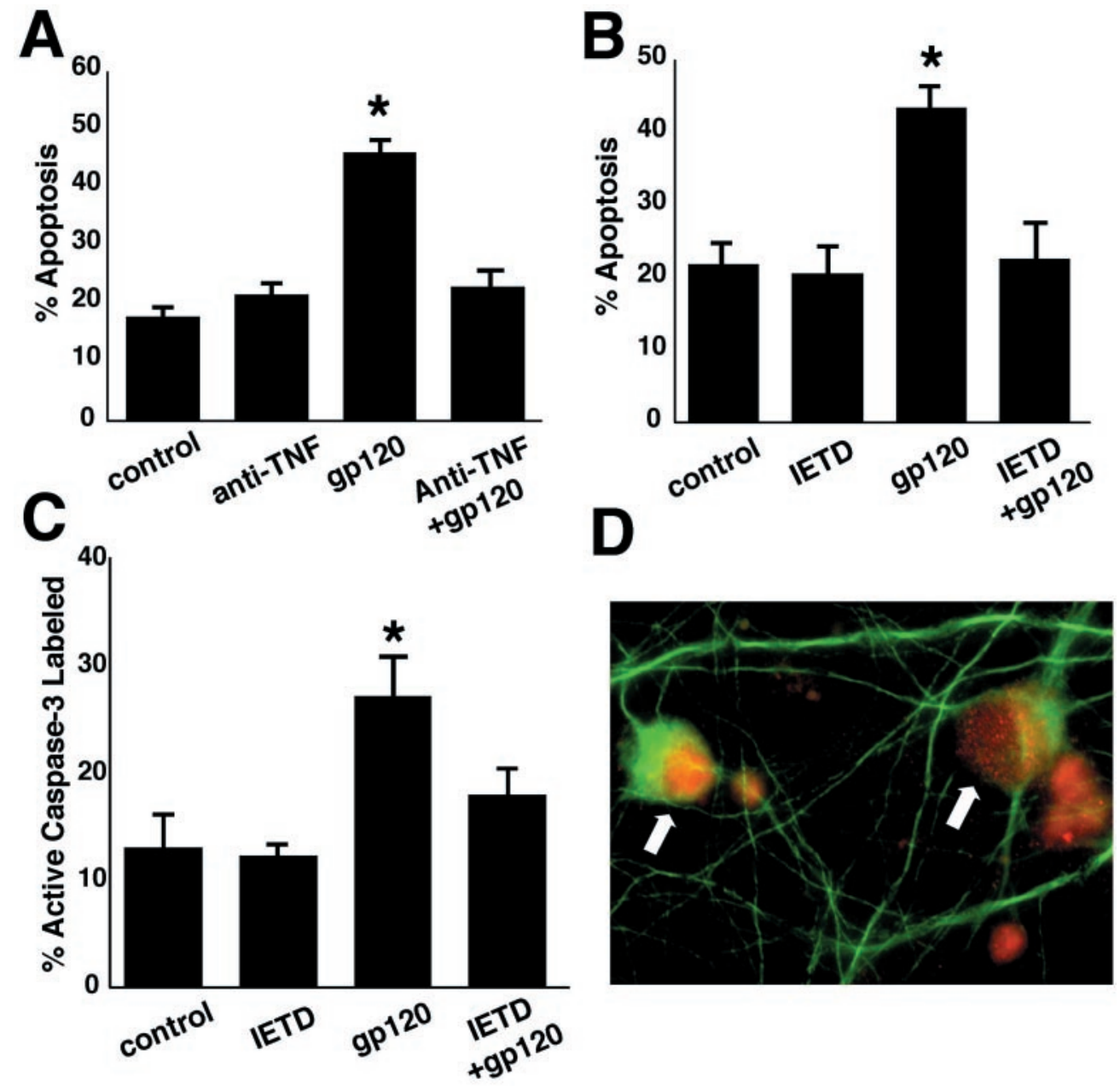

Figure 3. The caspase-8 pathway is involved in $\mathrm{HIV/gp} 120$-induced neuronal apoptosis. $A$, Neutralizing antibody to TNF- $\alpha$ prevented gp120-induced apoptosis $\left({ }^{*} p<0.001 ; n=6\right.$ from 2 independent experiments). $B, C$, Specific inhibition of caspase- 8 also prevented caspase- 3 activation ( ${ }^{*} p<0.02 ; n=6$ from 2 independent experiments) and apoptosis $\left({ }^{*} p<0.001 ; n=6\right.$ from 2 independent experiments) induced by exposure to gp120 for $24 \mathrm{hr}$. D Caspase- 8 was activated in neurons after exposure to gp120. Cultured neurons exposed to gp120 for $6 \mathrm{hr}$ were fixed and double immunostained with anti-MAP-2 (green) antibody and antiactive caspase-8 (red; arrows). Caspase- 8 was observed in the nuclei (red) and cytoplasm (yellow) of MAP2-labeled neurons. including neurons and glia, and are upregulated by inflammatory stimuli, including TNF- $\alpha$ (Nadeau and Rivest, 1999). To determine whether gp120 activates caspase- 8 specifically in neurons, cultures were colabeled with anti-active caspase- 8 and antiMAP-2. After a 6-18 hr exposure to gp120, numerous MAP-2positive neurons were immunoreactive for active caspase- 8 (Fig. $3 D$ ). Active caspase- 8 immunoreactivity was observed in neuronal cytoplasm and nuclei. In contrast, active caspase- 8 immunoreactivity did not colocalize with microglial-specific markers (data not shown). These results support a role for the death receptor-mediated caspase cascade in gp120-induced neuronal apoptosis.

\section{HIV/gp120-induced neuronal apoptosis involves caspase- 9 activation}

Apoptosis mediated by caspase- 9 activity is stimulated by elevation in intracellular $\mathrm{Ca}^{2+}$ and is associated with excitotoxic (glutamate-like) insults to neurons (Budd et al., 2000). Excitotoxic stimulation of the NMDA subtype of glutamate receptor leads to elevated $\left[\mathrm{Ca}^{2+}\right]_{\mathrm{i}}$, increased reactive oxygen species, and release of mitochondrial cytochrome $c$ into the cytoplasm (Luetjens et al., 2000). Cytoplasmic cytochrome $c$ is a required cofactor for caspase-9 activity (Stennicke and Salvesen, 2000). HIV-infected or immune-stimulated macrophages release quinolinate and other excitotoxic substances that overstimulate the NMDA receptor (Giulian et al., 1990, 1996). Elevated CSF quinolinate is associated with CNS pathology and dementia dur- ing HIV infection (Heyes et al., 1991). Additionally, in response to gp120 exposure, macrophage-microglial cells release large amounts of L-cysteine (Yeh et al., 2000), which can also excessively activate NMDA receptors (Olney et al., 1990). Previous work has shown that blockade of NMDA receptors inhibits gp120-induced neuronal injury and death in vitro (Lipton, 1992) and in vivo in gp120 transgenic mice (Toggas et al., 1996). Moreover, the mitochondrial caspase cascade is activated in cerebrocortical cultures treated with mild excitotoxic concentrations of NMDA (Budd et al., 2000). Therefore, we hypothesized that gp120-induced neuronal apoptosis may also involve the mitochondrial caspase pathway.

To begin to directly investigate whether the mitochondrial apoptotic cascade also has a role in HIV-induced neuronal injury, the presence of cytoplasmic cytochrome $c$ in cerebrocortical cultures exposed to gp120 was assessed. We found that cytochrome $c$ was released from mitochondria 3-12 hr after gp120 exposure (Fig. 4A). Additionally, inhibition of caspase-9 activity with the relatively specific inhibitor $20 \mu \mathrm{M}$ LEHD-fmk blocked activation of downstream neuronal caspase-3 and resulting apoptosis after a $24 \mathrm{hr}$ exposure to gp120 (Fig. 4B,C). Caspase-9 activity in gp120-exposed neurons was confirmed by immunofluorescence labeling with an antibody that recognizes only the active form of caspase-9 (Fig. 4D). Together, these findings strongly suggest that acute gp120-induced neuronal apoptosis also involves stimulation of the mitochondrial caspase cascade. 


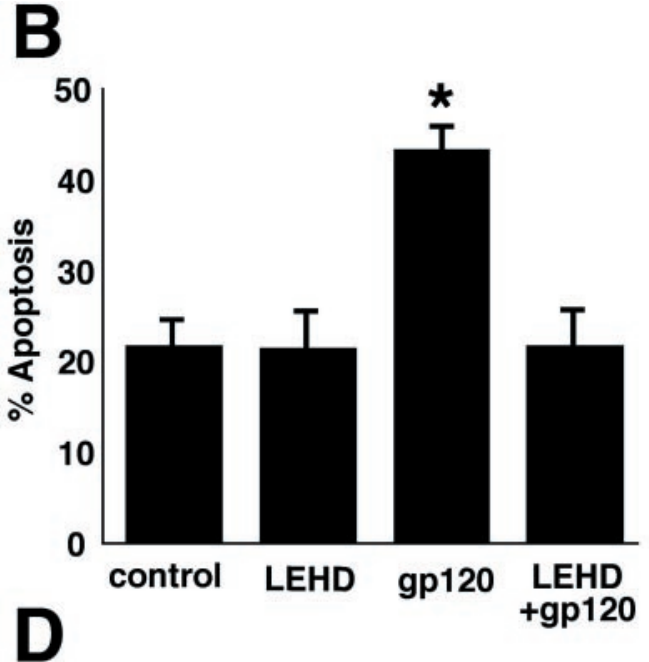

Figure 4. The mitochondrial caspase cascade is activated in cerebrocortical cultures exposed to $\mathrm{HIV} / \mathrm{gp} 120$, and caspase-9 inhibition prevents gp120induced apoptosis. $A$, Cerebrocortical cultures exposed to gp120 released cytochrome $c$ (cyto. $c$ ) into the cytoplasm after 3-12 hr. $B, C$, Preincubation with a specific inhibitor of caspase-9 prevented gp120-induced neuronal caspase- 3 activation $(* p<$ $0.005 ; n=6$ from 2 independent experiments) and neuronal apoptosis $\left({ }^{*} p<0.001 ; n=6\right.$ from 2 independent experiments). $D$, Caspase-9 activity (red; arrows) was observed in the nuclei of neurons (MAP-2 positive; green) after $6 \mathrm{hr}$ exposure to HIV/gp120.
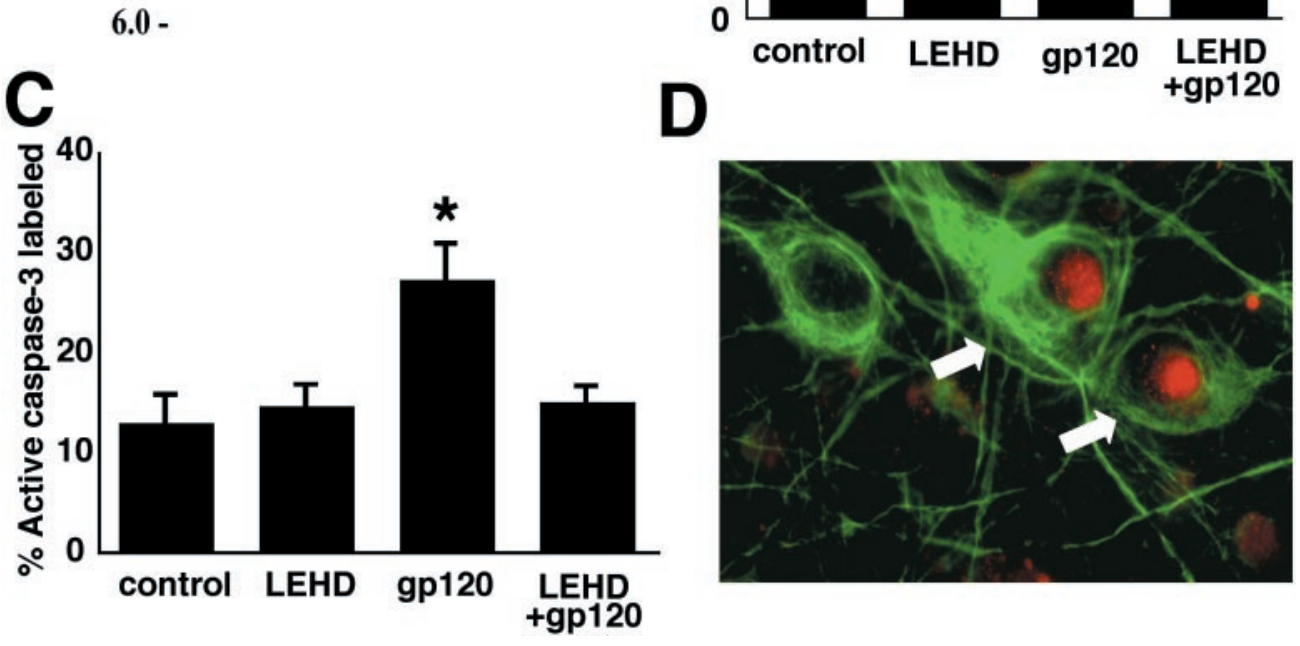

\section{Caspase inhibition prevents dendritic damage in HIV/ gp120 transgenic mice}

The degree of cortical neuronal apoptosis observed at any one time is not well correlated with the severity of HAD (AdleBiassette et al., 1999), but chronic dendritic injury is strongly correlated (Masliah et al., 1997). One reason for this may relate to the fact that apoptotic cells are quickly cleared by phagocytes in vivo, unlike the situation in vitro. In this regard, transgenic mice expressing HIV/gp120 develop a pattern of synaptic and dendritic injury similar to the neuropathology of HAD.

Previous work has shown that Casp-1/C285G transgenic mice develop normally, with no obvious neurologic phenotype, but are resistant to CNS injury induced by ischemia, trauma, oxidative injury, or mutant huntingtin protein (Friedlander et al., 1997; Fink et al., 1999; Ona et al., 1999; Andreassen et al., 2000; Li et al., 2000). Expression of the Casp-1/C285G transgene is directed predominantly to neurons by the NSE promoter, suggesting that the neuroprotection observed in these mice most likely occurs via intraneuronal caspase inhibition.

To produce a mouse model system in which to test the hypothesis that caspase enzymes may mediate the chronic dendritic injury observed in HAD, we crossed gp120 transgenic mice with Casp-1/C285G transgenic mice. Cortical dendritic volume was assessed by quantitative deconvolution microscopy from the $\mathrm{F} 3$ progeny of these crosses at 12 months of age (Fig. 5A) (see Materials and Methods). HIV/gp120 transgenic mice manifested a $25 \%$ reduction in dendritic volume $(p<0.0001)$ compared with wild-type littermates. In contrast, cortical dendritic volumes in mice containing the Casp-1/C285G transgene or bigenic for both the Casp-1/C285G and gp120 transgenes were not significantly

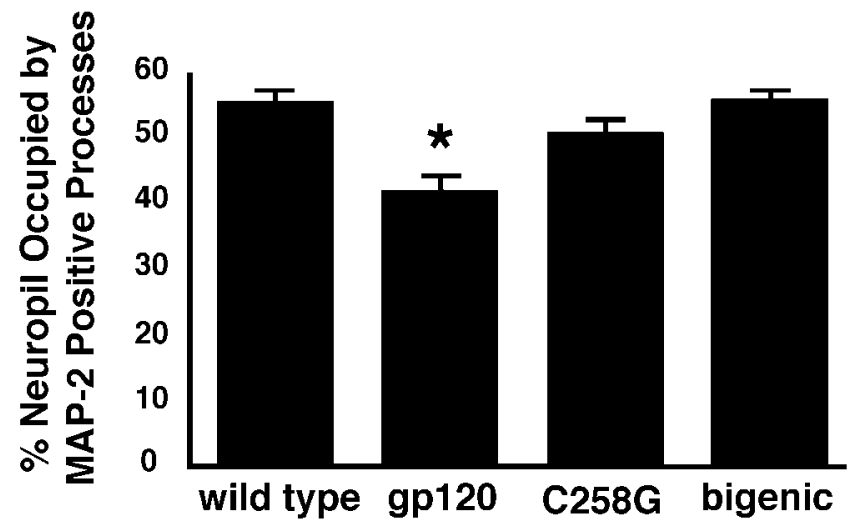

Figure 5. Caspase inhibition prevents dendritic injury in gp120 transgenic mice. The volume of cortical neuropil occupied by MAP-2-labeled processes was reduced in animals expressing the HIV/gp120 transgene. Coexpression of the Casp- $1 / \mathrm{C} 285 \mathrm{G}$ and gp120 transgenes resulted in cortical dendritic volumes that did not differ significantly from wild-type mice or Casp-1/C285G transgenic mice alone $\left({ }^{*} p<0.0001 ; n=5\right.$ per genotype).

different from wild type. A second line of gp120 transgenic mice generated using a more restricted region of the GFAP promoter to direct expression revealed nearly identical results (data not shown). These findings demonstrate that inhibition of neuronal caspase activity prevented dendritic injury in this mouse model of HAD.

Intraventricular administration of HIV/gp120 causes accumulation of mature IL- $1 \beta$ in rat brain mitochondria (Corasaniti et 
al., 2001). The $\mathrm{C} 285 \mathrm{G}$ transgene is capable of suppressing mature IL- $1 \beta$ production in brain but may also suppress the activity of additional caspases (Friedlander et al., 1997; Ona et al., 1999). Thus, it is possible that the suppression of dendritic injury in these animal is attributable to specific inhibition of caspase- 1 or blockade of mature IL- $1 \beta$ production. To further address this possibility, mixed cerebrocortical cultures from rat and mice were incubated with the specific caspase-1 inhibitor 2-Tyr-Val-AlaAsp-fluoromethyl ketone (YVAD) before HIV/gp120 exposure. No protective effect of YVAD on HIV/gp120-induced neuronal apoptosis was observed in mixed cerebrocortical cultures from either species (data not shown). This finding suggests that the ability of the $\mathrm{C} 285 \mathrm{G}$ transgene to prevent dendritic injury may be mediated by caspases other than caspase- 1 .

\section{DISCUSSION}

The work presented here demonstrates that HIV disease in the human brain is associated with an increase in neuronal immunoreactivity for the active form of caspase-3. Numerous cerebrocortical neurons examined in affected regions of human brain from patients with HIVE and a history of cognitive impairment (in contrast to both HIV-positive and HIV-negative controls) were immunoreactive for active caspase-3. Moreover, we predominantly found a diffuse pattern of immunoreactivity in neuronal cell bodies and processes, whereas active caspase-3 in neuronal nuclei was rarely observed. Using a different polyclonal antibody against active caspase-3, two groups reported recently a similar pattern of active caspase- 3 immunoreactivity without features of apoptosis in other neurodegenerative diseases, i.e., in cortical neurons from cases of frontotemporal dementia (Su et al., 2000), and in nigral neurons from patients with Parkinson's disease (Hartmann et al., 2000). These findings argue that active caspase-3 antibodies can recognize damaged cell bodies and processes in the absence of apoptotic changes in the nucleus. Additionally, microinjection of active caspase- 3 into cultured human neurons resulted in only $20 \%$ of the neurons undergoing apoptosis (Zhang et al., 2000). Taken in conjunction with our new findings, these reports suggest that caspase- 3 may participate in the neuronal response to injury without necessarily initiating an irreversible apoptotic cascade. Moreover, conformationally active caspase-3 has been localized to the neuronal cytoplasm acutely after NMDA exposure, $>12 \mathrm{hr}$ before accumulation of nuclear caspase- 3 and induction of the apoptotic cascade (Tenneti and Lipton, 2000). The findings support the notion that caspases may play a role in structural changes of synaptic plasticity and dendritic degeneration even in the absence of apoptosis. Nonetheless, caspases are not invariably associated with damage to neuronal processes. For example, caspase inhibition failed to prevent neurite loss from neuroblastoma cells exposed to oxidative stress (von Coelln et al., 2001), and caspase activation was not detected in injured axons, even when it was present in the dying somata (Finn et al., 2000).

Interestingly, neuronal apoptosis per se in HIV-positive brains correlates with evidence of axonal damage and markers of microglial activation but is not closely related to the presence of dementia (Adle-Biassette et al., 1999). In contrast, loss of synaptic structure and dendritic damage are the neuropathological findings most closely correlated with cognitive decline during HIV infection (Masliah et al., 1997; Everall et al., 1999). In the gp120 transgenic mouse model of HAD, neuronal loss occurs in a population of large cortical neurons $>100 \mu \mathrm{m}^{2}$ in area. However, more striking is the degree of dendritic injury observed in these mice (Toggas et al., 1994, 1996), suggesting that the pathology induced by gp120 exposure alone closely resembles the relevant pathology observed in patients with HAD. If caspase activity contributes to synaptic or dendritic damage in HAD, then inhibition of the specific caspases involved in that process could be an important therapeutic target for the prevention of HAD. Along these lines, we show here that transgenic neuronal expression of a dominant negative caspase prevents the dendritic injury observed in gp120 transgenic mice.

The caspase inhibitory transgene used in this experiment is a mutant form of caspase-1. Caspase-1, a member of the cytokine regulatory subfamily of caspases, is involved in the proteolytic processing of IL- $1 \beta$. Thus, it is possible that the effect of the $\mathrm{C} 258 \mathrm{G}$ transgene may be secondary to the lack of mature IL-1 $\beta$ production by neurons and subsequent suppression of microglial or astrocytic activation. However, overexpression of the C258G transgene may result in the generation of proteolytically inactive heterodimeric caspases, thereby decreasing the enzymatic function of multiple caspase family members. In addition, caspase- 1 inhibition alone failed to prevent HIV/gp120-induced neuronal apoptosis in vitro. Thus, we favor the hypothesis that nonspecific intraneuronal caspase inhibition resulting from the expression of the C258G transgene prevented gp120-induced dendritic degeneration in vivo.

To determine the upstream pathways that promote activation of caspase- 3 in neurons under these conditions, we studied the death receptor-mediated and mitochondrially mediated apoptotic cascades in an in vitro model of HIV-induced neuronal injury. This model system uses gp120 from the SF2 strain of HIV-1, which uses the CXCR4 class of chemokine receptor as a cofactor for viral entry and is generally considered a T-cell tropic strain. HIV strains isolated from patients with HAD and capable of infecting microglia are often $\mathrm{M}$ (macrophage)-tropic, interacting with the CCR5 class of chemokine receptor; however, CXCR4 (termed X4)-preferring virus may be more neurovirulent based on its ability to cause neuronal apoptosis in human cerebrocortical cultures according to recent studies (Ohagen et al., 1999). Although the $\mathrm{HIV}_{\mathrm{SF} 2}$ strain is not associated with macrophage tropism, it is clear that the gp120 from this strain is quite capable of causing neuronal apoptosis (Kaul and Lipton, 1999). Cell-type tropism of this strain is further complicated by the fact that $\mathrm{HIV}_{\mathrm{SF} 2}$ is clearly T-tropic in vitro but can also use CCR5 as a coreceptor for viral entry (Cheng-Mayer et al., 1997; Hung et al., 1999), a characteristic usually associated with dual-tropic strains. Furthermore, much of the toxicity of shed gp120 may be secondary to interaction with chemokine receptors, and gp120 from other T-tropic strains also induces neuronal apoptosis (Bezzi et al., 2001). After exposure to gp $120_{\mathrm{SF} 2}$, we found that activation of both caspase- 8 and caspase- 9 contributes to neuronal apoptosis.

We reported previously that neutralizing antibody to TNF- $\alpha$ prevented the release of L-cysteine from gp120-activated macrophage-microglial cells. In addition, recent reports demonstrate that TNF- $\alpha$ also promotes glutamate release from astrocytes (Bezzi et al., 2001). Therefore, the neuroprotective effect of antiTNF- $\alpha$ observed here may in part be secondary to its role in preventing release of compounds such as L-cysteine and glutamate from non-neuronal cells that secondarily activate the mitochondrial caspase cascade in neurons via NMDA receptor stimulation (Fig. 6) (Bezzi et al., 2001). However, immunocytochemical data (Fig. $3 D$ ) demonstrate that caspase- 8 is activated within neurons. Additionally, differentiated NT-2 (human neuroblastoma) cells undergo caspase-8 activation after exposure to HIV/gp120 (Patel 
Figure 6. Schematic model of pathways to caspase activation in HIV/gp120induced neuronal apoptosis. Microglia respond to gp120 by releasing excitotoxic molecules that overstimulate NMDA receptors on neurons. Excitotoxins such as glutamate are also released by astrocytes (data not shown). This leads to an excessive increase in neuronal $\left[\mathrm{Ca}^{2+}\right]_{i}$, promoting loss of mitochondrial membrane potential and release of cytochrome $c$ (Cyto. c). Cytoplasmic cytochrome $c$ in conjunction with apoptosis proteasesactivating factor- 1 and dATP lead to activation of the mitochondrial caspase pathway (large solid arrows) via activation of caspase-9. Microglia exposed to HIV/gp120 also release TNF- $\alpha$. Bound TNFRs can stimulate the caspase- 8 pathway (dashed arrows) in a series of steps leading to the cleavage and activation of caspase-8, although this caspase may possibly be activated by additional means. TNF- $\alpha$ also acts on microglia to promote release of excitotoxic compounds. Caspase- 8 cleaves the proapoptotic protein bid, resulting in translocation of the truncated bid (tbid) to mitochondria, cytochrome $c$ release, and activation of caspase-9. The downstream effect of both pathways is activation of caspase- 3 and apoptosis.

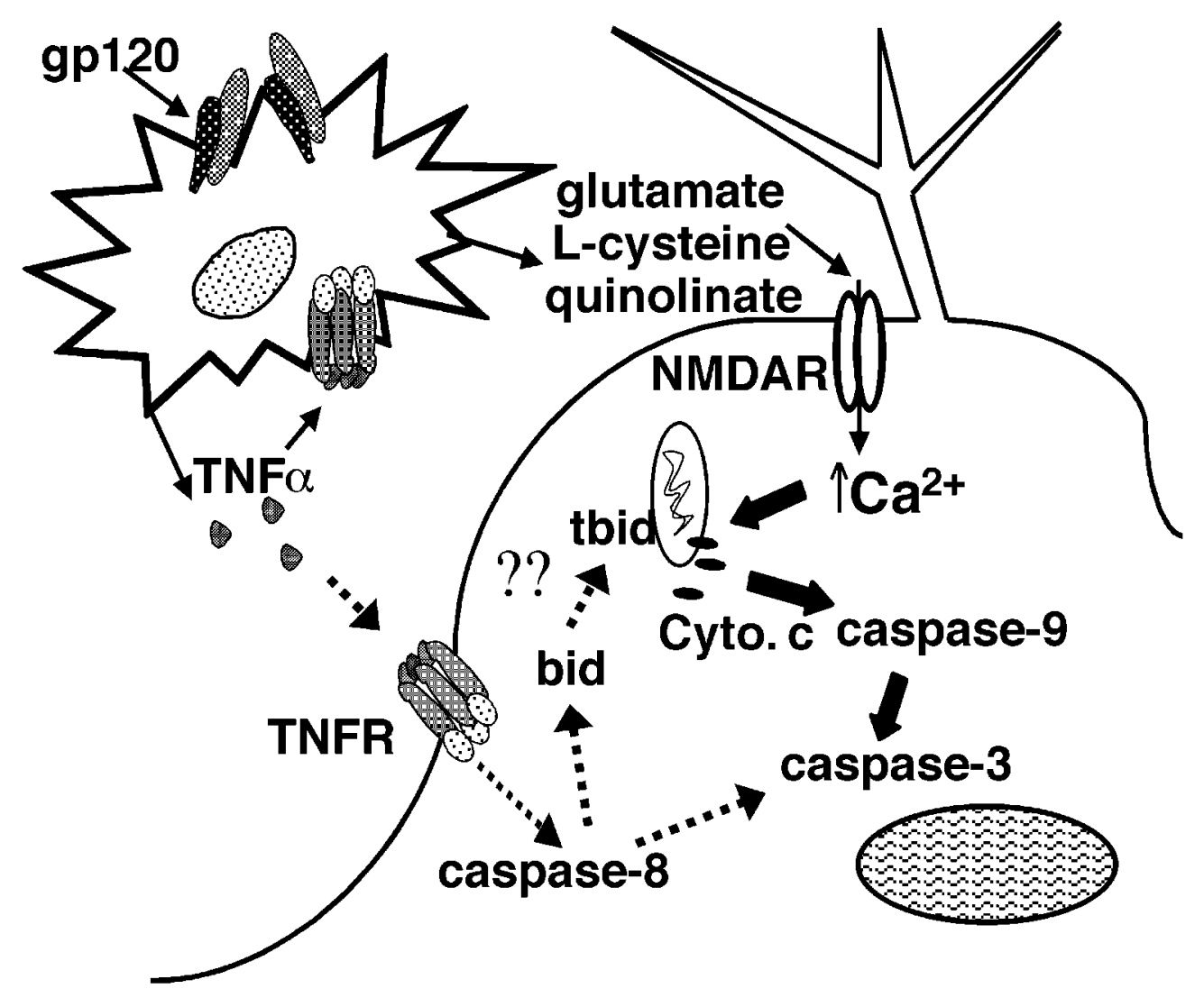

et al., 2000). These findings suggest a specific role for the death receptor-induced caspase pathway within neurons after exposure to $\mathrm{HIV} / \mathrm{gp} 120$ but do not rule out the possibility that caspase inhibition may also alter the microglial response to gp120 exposure. The mitochondrial caspase pathway was also implicated in our system because gp120 exposure led to the release of cytochrome $c$ from mitochondria. Moreover, the findings that gp120induced neuronal apoptosis was associated with immunocytochemical evidence for neuronal caspase- 9 activation and that caspase-9 inhibition prevented gp120-induced neuronal apoptosis also support a role for the mitochondrial caspase pathway in this process.

The cascade of caspase activation after exposure to HIV/gp120 likely represents one important component of the pathway to neuronal injury in HAD. The finding that gp120 transgenic mice manifest neuropathology similar to that observed in patients with HAD (Toggas et al., 1994) suggests that gp120 toxicity alone may be sufficient to explain a major portion of the neuronal injury. However, other HIV proteins, such as Vpr, Nef, and Tat, may also initiate the apoptotic signal transduction cascade in neurons and non-neuronal cells (Adamson et al., 1996; Kruman et al., 1998; New et al., 1998; Bartz and Emerman, 1999; Piller et al., 1999; Liu et al., 2000; Trillo-Pazos et al., 2000). Nonetheless, these other proteins appear to trigger apoptotic cell death in vitro only at much higher concentrations than that required for gp120induced neuronal apoptosis. The in vivo concentration of any shed HIV protein (including gp120) in the setting of HAD is not definitively known. Therefore, additional work is needed to determine the relationship of neurotoxicity in vitro to our understanding of the pathogenesis of HAD.

A schematic representation of caspase activation in HIV/ gp120-induced neuronal apoptosis is illustrated in Figure 6. Pre- vious studies have shown that macrophage-microglial cells exposed to HIV or recombinant gp120 release TNF- $\alpha$ and excitotoxins (Lipton and Gendelman, 1995; Kaul et al., 2001). The present study demonstrates that exposing rat cerebrocortical cultures to HIV/gp120 promotes specific caspase activities, including caspase-8, caspase-9, and caspase-3, associated with stimulation by cytokines or excitatory amino acids. The proapoptotic protein bid is a substrate for caspase- 8 and may serve as a link between the death receptor and mitochondrial caspase pathways (Li et al., 1998; Luo et al., 1998). However, the relationship between caspase- 8 , bid, and cytochrome $c$ release has yet to be demonstrated specifically in neurons. Recently, caspase- 8 proteolytic cleavage and bid truncation were detected in hippocampal tissue after a large excitotoxic stimulus (Henshall et al., 2001), but these were not specifically localized to the neuronal population.

The data presented here provide support for the theory that synergy between the upstream caspase pathways may have an important role in gp120-induced neuronal apoptosis. Inhibition of either caspase- 8 or caspase- 9 prevented activation of caspase- 3 and resulting neuronal apoptosis after $24 \mathrm{hr}$ of gp120 exposure. Together, the data reported here support an important function for caspase enzymes in HIV-related neuronal injury and apoptosis. Our results also suggest potential treatment targets for the prevention of HIV-induced neuronal injury, such as caspase inhibitors or compounds that inhibit the interaction between TNF- $\alpha$ and its receptor.

\section{REFERENCES}

Adamson DC, Wildemann B, Sasaki M, Glass JD, McArthur JC, Christov VI, Dawson TM, Dawson VL (1996) Immunologic NO synthase: elevation in severe AIDS dementia and induction by HIV-1 gp41. Science 274:1917-1921.

Adle-Biassette H, Levy Y, Colombel M, Poron F, Natchev S, Keohane C, 
Gray F (1995) Neuronal apoptosis in HIV infection in adults. Neuropathol Appl Neurobiol 21:218-227.

Adle-Biassette H, Chretien F, Wingertsmann L, Hery C, Ereau T, Scaravilli F, Tardieu M, Gray F (1999) Neuronal apoptosis does not correlate with dementia in HIV infection but is related to microglial activation and axonal damage. Neuropathol Appl Neurobiol 25:123-133.

Andreassen OA, Ferrante RJ, Hughes DB, Klivenyi P, Dedeoglu A, Ona VO, Friedlander RM, Beal MF (2000) Malonate and 3-nitropropionic acid neurotoxicity are reduced in transgenic mice expressing a caspase-1 dominant-negative mutant. J Neurochem 75:847-852.

Bartz SR, Emerman M (1999) Human immunodeficiency virus type 1 Tat induces apoptosis and increases sensitivity to apoptotic signals by up-regulating FLICE/caspase-8. J Virol 73:1956-1963.

Bezzi P, Domercq M, Brambilla L, Galli R, Schols D, De Clercq E, Vescovi A, Bagetta G, Kollias G, Meldolesi J, Volterra A (2001) CXCR4-activated astrocyte glutamate release via TNFalpha: amplification by microglia triggers neurotoxicity. Nat Neurosci 4:702-710.

Brenneman DE, Westbrook GL, Fitzgerald SP, Ennist DL, Elkins KL, Ruff MR, Pert CB (1988) Neuronal cell killing by the envelope protein of HIV and its prevention by vasoactive intestinal peptide. Nature 335:639-642.

Budd SL, Tenneti L, Lishnak T, Lipton SA (2000) Mitochondrial and extramitochondrial apoptotic signaling pathways in cerebrocortical neurons. Proc Natl Acad Sci USA 97:6161-6166.

Cheng-Mayer C, Liu R, Landau NR, Stamatatos L (1997) Macrophage tropism of human immunodeficiency virus type 1 and utilization of the CC-CKR5 coreceptor. J Virol 71:1657-1661.

Corasaniti MT, Turano P, Bilotta A, Malorni W, Stringaro AR, Nistico R, Finazzi-Agro A, Bagetta G (2001) Evidence that increases of mitochondrial immunoreactive IL-1beta by HIV-1 gp120 implicate in situ cleavage of pro-IL-1beta in the neocortex of rat. J Neurochem 78:611-618.

Dreyer EB, Kaiser PK, Offermann JT, Lipton SA (1990) HIV-1 coat protein neurotoxicity prevented by calcium channel antagonists. Science 248:364-367.

Everall IP, Heaton RK, Marcotte TD, Ellis RJ, McCutchan JA, Atkinson JH, Grant I, Mallory M, Masliah E (1999) Cortical synaptic density is reduced in mild to moderate human immunodeficiency virus neurocognitive disorder. HNRC Group. HIV Neurobehavioral Research Center. Brain Pathol 9:209-217.

Fink KB, Andrews LJ, Butler WE, Ona VO, Li M, Bogdanov M, Endres M, Khan SQ, Namura S, Stieg PE, Beal MF, Moskowitz MA, Yuan J, Friedlander RM (1999) Reduction of post-traumatic brain injury and free radical production by inhibition of the caspase-1 cascade. Neuroscience 94:1213-1218.

Finn JT, Weil M, Archer F, Siman R, Srinivasan A, Raff MC (2000) Evidence that Wallerian degeneration and localized axon degeneration induced by local neurotrophin deprivation do not involve caspases. J Neurosci 20:1333-1341.

Friedlander RM, Gagliardini V, Hara H, Fink KB, Li W, MacDonald G, Fishman MC, Greenberg AH, Moskowitz MA, Yuan J (1997) Expression of a dominant negative mutant of interleukin-1 beta converting enzyme in transgenic mice prevents neuronal cell death induced by trophic factor withdrawal and ischemic brain injury. J Exp Med 185:933-940.

Gelbard HA, James HJ, Sharer LR, Perry SW, Saito Y, Kazee AM, Blumberg BM, Epstein LG (1995) Apoptotic neurons in brains from paediatric patients with HIV-1 encephalitis and progressive encephalopathy. Neuropathol Appl Neurobiol 21:208-217.

Giulian D, Vaca K, Noonan CA (1990) Secretion of neurotoxins by mononuclear phagocytes infected with HIV-1. Science 250:1593-1596.

Giulian D, Wendt E, Vaca K, Noonan CA (1993) The envelope glycoprotein of human immunodeficiency virus type 1 stimulates release of neurotoxins from monocytes. Proc Natl Acad Sci USA 90:2769-2773.

Giulian D, Yu J, Li X, Tom D, Li J, Wendt E, Lin SN, Schwarcz R, Noonan C (1996) Study of receptor-mediated neurotoxins released by HIV-1-infected mononuclear phagocytes found in human brain. J Neurosci 16:3139-3153.

Hartmann A, Hunot S, Michel PP, Muriel MP, Vyas S, Faucheux BA, Mouatt-Prigent A, Turmel H, Srinivasan A, Ruberg M, Evan GI, Agid Y, Hirsch EC (2000) Caspase-3: a vulnerability factor and final effector in apoptotic death of dopaminergic neurons in Parkinson's disease. Proc Natl Acad Sci USA 97:2875-2880.

Henshall DC, Bonislawski DP, Skradski SL, Lan JQ, Meller R, Simon RP (2001) Cleavage of bid may amplify caspase-8-induced neuronal death following focally evoked limbic seizures. Neurobiol Dis 8:568-580.

Hesselgesser J, Taub D, Baskar P, Greenberg M, Hoxie J, Kolson DL, Horuk R (1998) Neuronal apoptosis induced by HIV-1 gp120 and the chemokine SDF-1 alpha is mediated by the chemokine receptor CXCR4. Curr Biol 8:595-598.

Heyes MP, Brew BJ, Martin A, Price RW, Salazar AM, Sidtis JJ, Yergey JA, Mouradian MM, Sadler AE, Keilp J, Rubinow D, Markey SP (1991) Quinolinic acid in cerebrospinal fluid and serum in HIV-1 infection: relationship to clinical and neurological status. Ann Neurol 29:202-209.
Huang MB, Weeks O, Zhao LJ, Saltarelli M, Bond VC (2000) Effects of extracellular human immunodeficiency virus type $1 \mathrm{vpr}$ protein in primary rat cortical cell cultures. J Neurovirol 6:202-220.

Hung CS, Vander Heyden N, Ratner L (1999) Analysis of the critical domain in the V3 loop of human immunodeficiency virus type 1 gp120 involved in CCR5 utilization. J Virol 73:8216-8226.

Imai Y, Kimura T, Murakami A, Yajima N, Sakamaki K, Yonehara S (1999) The CED-4-homologous protein FLASH is involved in Fasmediated activation of caspase-8 during apoptosis. Nature 398:777-785.

James HJ, Sharer LR, Zhang Q, Wang HG, Epstein LG, Reed JC Gelbard HA (1999) Expression of caspase-3 in brains from paediatric patients with HIV-1 encephalitis. Neuropathol Appl Neurobiol 25:380-386

Kaul M, Lipton SA (1999) Chemokines and activated macrophages in HIV gp120-induced neuronal apoptosis. Proc Natl Acad Sci USA 96:8212-8216.

Kaul M, Garden GA, Lipton SA (2001) Pathways to neuronal injury and apoptosis in HIV-associated dementia. Nature 410:988-994.

Kruman II, Nath A, Mattson MP (1998) HIV-1 protein Tat induces apoptosis of hippocampal neurons by a mechanism involving caspase activation, calcium overload, and oxidative stress. Exp Neurol 154:276-288.

Lavi E, Kolson DL, Ulrich AM, Fu L, Gonzalez-Scarano F (1998) Chemokine receptors in the human brain and their relationship to HIV infection. J Neurovirol 4:301-311.

Li H, Zhu H, Xu CJ, Yuan J (1998) Cleavage of BID by caspase 8 mediates the mitochondrial damage in the Fas pathway of apoptosis. Cell 94:491-501.

Li M, Ona VO, Chen M, Kaul M, Tenneti L, Zhang X, Stieg PE, Lipton SA, Friedlander RM (2000) Functional role and therapeutic implications of neuronal caspase- 1 and -3 in a mouse model of traumatic spinal cord injury. Neuroscience 99:333-342.

Lipton SA (1992) Memantine prevents HIV coat protein-induced neuronal injury in vitro. Neurology 42:1403-1405.

Lipton SA, Gendelman HE (1995) Seminars in medicine of the Beth Israel Hospital, Boston. Dementia associated with the acquired immunodeficiency syndrome. N Engl J Med 332:934-940.

Liu Y, Jones M, Hingtgen CM, Bu G, Laribee N, Tanzi RE, Moir RD, Nath A, He JJ (2000) Uptake of HIV-1 Tat protein mediated by low-density lipoprotein receptor-related protein disrupts the neuronal metabolic balance of the receptor ligands. Nat Med 6:1380-1387.

Luetjens CM, Bui NT, Sengpiel B, Munstermann G, Poppe M, Krohn AJ, Bauerbach E, Krieglstein J, Prehn JH (2000) Delayed mitochondrial dysfunction in excitotoxic neuron death: cytochrome $c$ release and a secondary increase in superoxide production. J Neurosci 20:5715-5723.

Luo X, Budihardjo I, Zou H, Slaughter C, Wang X (1998) Bid, a Bcl2 interacting protein, mediates cytochrome c release from mitochondria in response to activation of cell surface death receptors. Cell 94:481490.

Masliah E, Ge N, Mucke L (1996) Pathogenesis of HIV-1 associated neurodegeneration. Crit Rev Neurobiol 10:57-67.

Masliah E, Heaton RK, Marcotte TD, Ellis RJ, Wiley CA, Mallory M, Achim CL, McCutchan JA, Nelson JA, Atkinson JH, Grant I (1997) Dendritic injury is a pathological substrate for human immunodeficiency virus-related cognitive disorders. HNRC Group. The HIV Neurobehavioral Research Center. Ann Neurol 42:963-972.

McArthur JC, Hoover DR, Bacellar H, Miller EN, Cohen BA, Becker JT, Graham NM, McArthur JH, Selnes OA, Jacobson LP (1993) Dementia in AIDS patients: incidence and risk factors. Multicenter AIDS Cohort Study. Neurology 43:2245-2252.

Meucci O, Fatatis A, Simen AA, Bushell TJ, Gray PW, Miller RJ (1998) Chemokines regulate hippocampal neuronal signaling and gp120 neurotoxicity. Proc Natl Acad Sci USA 95:14500-14505.

Nadeau S, Rivest S (1999) Effects of circulating tumor necrosis factor on the neuronal activity and expression of the genes encoding the tumor necrosis factor receptors (p55 and p75) in the rat brain: a view from the blood-brain barrier. Neuroscience 93:1449-1464.

Namura S, Z hu J, Fink K, Endres M, Srinivasan A, Tomaselli KJ, Yuan J, Moskowitz MA (1998) Activation and cleavage of caspase-3 in apoptosis induced by experimental cerebral ischemia. J Neurosci 18: 3659-3668.

New DR, Ma M, Epstein LG, Nath A, Gelbard HA (1997) Human immunodeficiency virus type 1 Tat protein induces death by apoptosis in primary human neuron cultures. J Neurovirol 3:168-173.

New DR, Maggirwar SB, Epstein LG, Dewhurst S, Gelbard HA (1998) HIV-1 Tat induces neuronal death via tumor necrosis factor-alpha and activation of non- $N$-methyl-D-aspartate receptors by a NFkappaB- independent mechanism. J Biol Chem 273:17852-17858.

Nitsch R, Bechmann I, Deisz RA, Haas D, Lehmann TN, Wendling U, Zipp F (2000) Human brain-cell death induced by tumournecrosis-factor-related apoptosis-inducing ligand (TRAIL). Lancet 356:827-828.

Ohagen A, Ghosh S, He J, Huang K, Chen Y, Yuan M, Osathanondh R, Gartner S, Shi B, Shaw G, Gabuzda D (1999) Apoptosis induced by infection of primary brain cultures with diverse human immunodefi- 
ciency virus type 1 isolates: evidence for a role of the envelope. J Virol 73:897-906.

Olney JW, Zorumski C, Price MT, Labruyere J (1990) L-cysteine, a bicarbonate-sensitive endogenous excitotoxin. Science 248:596-599.

Ona VO, Li M, Vonsattel JP, Andrews LJ, Khan SQ, Chung WM, Frey AS, Menon AS, Li XJ, Stieg PE, Yuan J, Penney JB, Young AB, Cha JH, Friedlander RM (1999) Inhibition of caspase-1 slows disease progression in a mouse model of Huntington's disease. Nature 399:263-267.

Patel CA, Mukhtar M, Pomerantz RJ (2000) Human immunodeficiency virus type $1 \mathrm{Vpr}$ induces apoptosis in human neuronal cells. J Virol 74:9717-9726.

Petito CK, Roberts B (1995) Evidence of apoptotic cell death in HIV encephalitis. Am J Pathol 146:1121-1130.

Piller SC, Ewart GD, Jans DA, Gage PW, Cox GB (1999) The aminoterminal region of $\mathrm{Vpr}$ from human immunodeficiency virus type 1 forms ion channels and kills neurons. J Virol 73:4230-4238.

Pulliam L, Zhou M, Stubblebine M, Bitler CM (1998) Differential modulation of cell death proteins in human brain cells by tumor necrosis factor alpha and platelet activating factor. J Neurosci Res 54:530-538.

Salvesen GS, Dixit VM (1999) Caspase activation: the inducedproximity model. Proc Natl Acad Sci USA 96:10964-10967.

Shi B, De Girolami U, He J, Wang S, Lorenzo A, Busciglio J, Gabuzda D (1996) Apoptosis induced by HIV-1 infection of the central nervous system. J Clin Invest 98:1979-1990.

Sippy BD, Hofman FM, Wallach D, Hinton DR (1995) Increased expression of tumor necrosis factor-alpha receptors in the brains of patients with AIDS. J Acquir Immune Defic Syndr Hum Retrovirol 10:511-521.

Stennicke HR, Salvesen GS (2000) Caspases-controlling intracellular signals by protease zymogen activation. Biochim Biophys Acta 1477:299-306

Su JH, Nichol KE, Sitch T, Sheu P, Chubb C, Miller BL, Tomaselli KJ, Kim RC, Cotman CW (2000) DNA damage and activated caspase-3 expression in neurons and astrocytes: evidence for apoptosis in frontotemporal dementia. Exp Neurol 163:9-19.

Talley AK, Dewhurst S, Perry SW, Dollard SC, Gummuluru S, Fine SM, New D, Epstein LG, Gendelman HE, Gelbard HA (1995) Tumor necrosis factor alpha-induced apoptosis in human neuronal cells: protection by the antioxidant $N$-acetylcysteine and the genes bcl- 2 and crmA. Mol Cell Biol 15:2359-2366.
Tenneti L, Lipton SA (2000) Involvement of activated caspase-3-like proteases in $N$-methyl-D-aspartate-induced apoptosis in cerebrocortical neurons. J Neurochem 74:134-142.

Toggas SM, Masliah E, Rockenstein EM, Rall GF, Abraham CR, Mucke L (1994) Central nervous system damage produced by expression of the HIV-1 coat protein gp120 in transgenic mice. Nature 367:188-193.

Toggas SM, Masliah E, Mucke L (1996) Prevention of HIV-1 gp120induced neuronal damage in the central nervous system of transgenic mice by the NMDA receptor antagonist memantine. Brain Res 706:303-307.

Trillo-Pazos G, McFarlane-Abdulla E, Campbell IC, Pilkington GJ, Everall IP (2000) Recombinant nef HIV-IIIB protein is toxic to human neurons in culture. Brain Res 864:315-326.

Velier JJ, Ellison JA, Kikly KK, Spera PA, Barone FC, Feuerstein GZ (1999) Caspase-8 and caspase-3 are expressed by different populations of cortical neurons undergoing delayed cell death after focal stroke in the rat. J Neurosci 19:5932-5941.

von Coelln R, Kugler S, Bahr M, Weller M, Dichgans J, Schulz JB (2001) Rescue from death but not from functional impairment: caspase inhibition protects dopaminergic cells against 6-hydroxydopamine-induced apoptosis but not against the loss of their terminals. J Neurochem 77:263-273.

Yeh MW, Kaul M, Zheng J, Nottet HS, Thylin M, Gendelman HE, Lipton SA (2000) Cytokine-stimulated, but not HIV-infected, human monocyte-derived macrophages produce neurotoxic levels of 1-cysteine. J Immunol 164:4265-4270.

Yeung MC, Pulliam L, Lau AS (1995) The HIV envelope protein gp120 is toxic to human brain-cell cultures through the induction of interleukin-6 and tumor necrosis factor-alpha. AIDS 9:137-143.

Yeung MC, Geertsma F, Liu J, Lau AS (1998) Inhibition of HIV-1 gp120-induced apoptosis in neuroblastoma SK-N-SH cells by an antisense oligodeoxynucleotide against p53. AIDS 12:349-354.

Zhang Y, Goodyer C, LeBlanc A (2000) Selective and protracted apoptosis in human primary neurons microinjected with active caspase-3, $-6,-7$, and -8. J Neurosci 20:8384-8389.

Zheng J, Thylin MR, Ghorpade A, Xiong H, Persidsky Y, Cotter R, Niemann D, Che M, Zeng YC, Gelbard HA, Shepard RB, Swartz JM, Gendelman HE (1999) Intracellular CXCR4 signaling, neuronal apoptosis and neuropathogenic mechanisms of HIV-1-associated dementia. J Neuroimmunol 98:185-200. 